\title{
O INVESTIMENTO ESTRANGEIRO EM FACE DOS INTERESSES NACIONAIS
}

\begin{abstract}
"Para os milionários norte-americanos transformados em governantes a América Latina surgiu como fácil prêsa, um "grande negócio". Os habitantes desta parte do mundo passaram a ser considerados como operários internacionais. A exploração, nos seus múltiplos aspectos, foi realizada com inteligência, sagacidade, precisão cronométrica, frieza "científica", rudeza e grande arrogância. Partindo do Sul, o rio dos milhôes começou a fluir em direção ao Norte, e a cada ano mais se avolumou. Os Estados Unidos tornaram-se grandes, enquanto que o progresso da América Latina foi estancado. E, quando algo ou alguém tentou interferir junto aos banqueiros ou às companhias, foram utilizados os fuzileiros navais..." JuAN José ARÉvalo
\end{abstract}

Para a maioria dos norte-americanos que conhecem algo sôbre as operaçóes de suas emprêsas no exterior (especialmente os que estão diretamente ligados a êsses empreendimentos) a vitalidade e a persistência das caricaturas de vorazes milionários ianques chegam a frustrar e confundir. Certa vez, como todo o empresário norte-americano sabe, havia uma United Fruit Company que estava profundamente envolvida na política das "repúblicas da banana".

Raymond Vernon - Professor de Relações Econômicas Internacionais, da Escola Graduada de Administração de Emprêsas, da Universidade de Harvard.

NotA DA REDAÇÃo: Este artigo é reproduzido com autorização da revista Harvard Business Review, onde foi publicado em maio/junho de 1963, vol. 41, n. ${ }^{\circ}$, sob o título original de Saints and Sinners in Foreign Investment. Traduzido do inglês por Frediano Quilici. 
E certa vez, como os nossos livros de história ensinam, os fuzileiros navais desembarcaram em Vera Cruz. Mas isso foi há muito tempo - pelo menos de acôrdo com a recordação das emprêsas norte-americanas .

Hoje em dia, onde quer que existam emprêsas norte-americanas, elas geralmente tendem a estabelecer os padrões nacionais de honestidade no pagamento dos impostos, decência nas relações trabalhistas, dedicação ao crescimento e ao desenvolvimento, e discrição quanto ao seu envolvimento nos problemas políticos internos.

Porque, então, persiste na América Latina, na África e na Ásia, essa imagem desatualizada, tão amargamente retratada no "O Tubarão e as Sardinhas" de JuAN José ARÉVALO, que acima mencionamos? $\mathrm{E}$ por que o fantasma dessa imagem invade ainda nações como o Canadá, a Austrália e a França?

Uma dificuldade na procura da resposta é o fato de que muitos norte-zmericanos imaginam já a terem encontrado. Em suas discussões a respeito da orientação futura da Aliança para o Progresso, por exemplo, muitos empresários norte-americanos acreditam que os latino-americanos contrários ao investimento privado estrangeiro sejam geralmente contrários, também, ao investimento privado nacional - que sejam, em suma, insensiveis a qualquer conceito do sistema da livre emprêsa.

Não é uma opinião totalmente infundada. Em alguns países, é claro, muito da oposição ao investimento estrangeiro representa caso especial de oposição à livre emprêsa em geral. Mas, grande parte da oposição é de natureza completamente diversa. Parte reflete aversão aos estrangeiros - governos ou particulares. Parte representa a resposta dos economistas e de outros técnicos às consequiências econômicas (reais ou imaginárias) do investimento estrangeiro sôbre a economia local. E parte é a resposta dos empresários locais - e não de socialistas ou de técnicos governamentais - à concorrência em seus negócios por rivais financiados no estrangeiro. 
A primeira necessidade de defesa é o conhecimento das táticas do adversário. Para responder de maneira efetiva à hostilidade tão freqüentemente dirigida aos investidores norte-americanos no exterior temos necessidade de compreender a razão dessa hostilidade. Neste artigo desejo tratar de alguns dos fundamentos econômicos do sentimento anti-americano e sugerir algumas medidas que poderão servir para reduzir a desconfiança de ambos os lados.

\section{O ECO DA HISTORIA}

Uma razão para a hostilidade pode ser encontrada na História - pelo menos como é esta agora compreendida pelos professôres e escritores das nações subdesenvolvidas. Entre os intelectuais, por exemplo, é crença corrente que os europeus e norte-americanos que investiram na América Latina durante o Século XIX realizaram um negócioda-china às expensas das nações latino-americanas. Alguns investidores, é certo, obtiveram grandes lucros. Más estudos mais sóbrios sôbre o investimento estrangeirn (como o realizado por J. FRED RIPPY, em seu livro British Investments in Latin America, 1822-1949), ${ }^{1}$ sugerem que a experiência do Século XIX, considerada em seu conjunto, produziu retornos bastante moderados para os investimentos estrangeiros .

Durante aquêle século grandes emissões de obrigações ao portador foram colocadas nas nações ricas da Europa para a construção de ferrovias e melhoramento de portos das nações mais pobres; para o financiamento da importação de vagões, aço e maquinaria; e para sustentar os funcionários locais que tornaram possíveis essas transações. Qualquer fluxo de capitais estrangeiros como êsse pode acarretar problemas de remessa ou transferência. Mas o problema de transferência no Século XIX foi muitas vêzes resolvido na América Latina por falência e falta de

1) Mineápolis: University of Minnesota Press, 1959. 
pagamento. A história do México no Século XIX, por exemplo, apresenta casos de acôrdos com aceitação de pagamento de 10 cents por dólar de débito não liquidado. O Século XIX, igualmente, foi testemunha de outro tipo de investimento estrangeiro: investimentos de europeus e norte-americanos na indústria de mineração e na agricultura de exportação. Em acentuado contraste com o ingrato negócio da compra de obrigações, essas atividades produziram algumas grandes fortunas para os estrangeiros. Foram essas operações que criaram a primitiva imagern do investimento estrangeiro na América Latina, África e Ásia.

A posição psicológica básica da maioria dêsses investidores era a de se envolverem o menos possível na economia local. O de que os empreendimentos estrangeiros na mineração e as companhias de plantação do Chile, Peru, México e América Central necessitavam, acima de tudo, das nações onde se instalavam, era segurança, suprimento de mão-de-obra e transporte para o mar. Se fôsse possível satisfazer essas necessidades dentro de um enclave, seria essa a situação ideal. Caso fôsse inevitável um envolvimento com a economia nacional, convinha restringi-lo ao mínimo.

Naturalmente, com o decorrer dos anos, a existência das companhias de mineração e agrícolas provocou vários efeitos secundários sôbre as economias nas quais operavam. Em alguns países, como o México e o Chile, as companhias atraíram emigrantes especializados, produzindo um grupo local de administradores médios. Em quase todos os paises operações dessa natureza ajudaram a fornecer base para estabelecimento ou expansão de um sistema ferroviário e de estações de fôrça.

Depois da Primeira Grande Guerra - como muitas companhias estrangeiras de mineração e de plantação começaram a perceber que a segurança de seus enclaves dependia, em parte, da satisfação de seus habitantes - começaram a aparecer casos nos quais o alojamento, as escolas, 
os hospitais e os serviços de utilidade das companhias estrangeiras eram os melhores que podiam ser obtidos no país. Companhias como a ARAMCO, na Arábia Saudita, a Firestone, na Libéria, a $W . R$. Grace, no Pétut, e a perseguida na história United Fruit, na América Central, tornaram-se hóspedes exemplares da's regiões onde operavăm. Mas eram convidados cujo principal interêsse estava ligado às matérias-primas da nação hospedeira, e não à própria nação. Nos países em que havia um sentimento histórico de inferioridade os enclaves nos quais os estrangeiros operavam constituíam-se símbolos constantes do caráter de segunda-classe da soberania nacional.

Certamente, muito disto é história antiga: E, embora grande seja ainda sua relevância, ela reflete principalmente as recordações do passado, e não os aconttecimentos atuais. Os dados do Gráfico 1 refletem o fato de que desde 1929, enquanto o total dos investimentos diretos * norte-americanos quadruplicou, os investimentos diretos no tipo antigo de agricultura realmente diminuíram.

Os investimentos na mineração esstão diminuindo de importância; e a maior parte do aumento verificado tem sido no Canadá, área de pressão comparativamente baixa. Os investimentos petrolíferos, a sermos exatos, têm-se expandido em tốda a parte - no Canadá, no Oriente Médio, na África, e em regióes da América Latina. Mas os têrmos das concessões de exploração nos dias que correm são dramàticamente diferentes daqueles de 10 ou 15 anos atrás. As companhias petrolíferas internacionais dificilmente podem ser descritas hoje como as arrogantes poderosas que poderiam pretender ser antigamente.

Entretanto, o nais importante de tudo é o fato de que recentemente nova modalidade de investimento direto tem crescido de maneira espetaicular, um tipo que tem como efeito automático envolver intimamente o investiclór estrangeiro nos destinos e vicissitudes da naçãŭ hospedèira. Refiro-me aos investimentos para fabricaçãó e venda de produtos no mercado interno. 


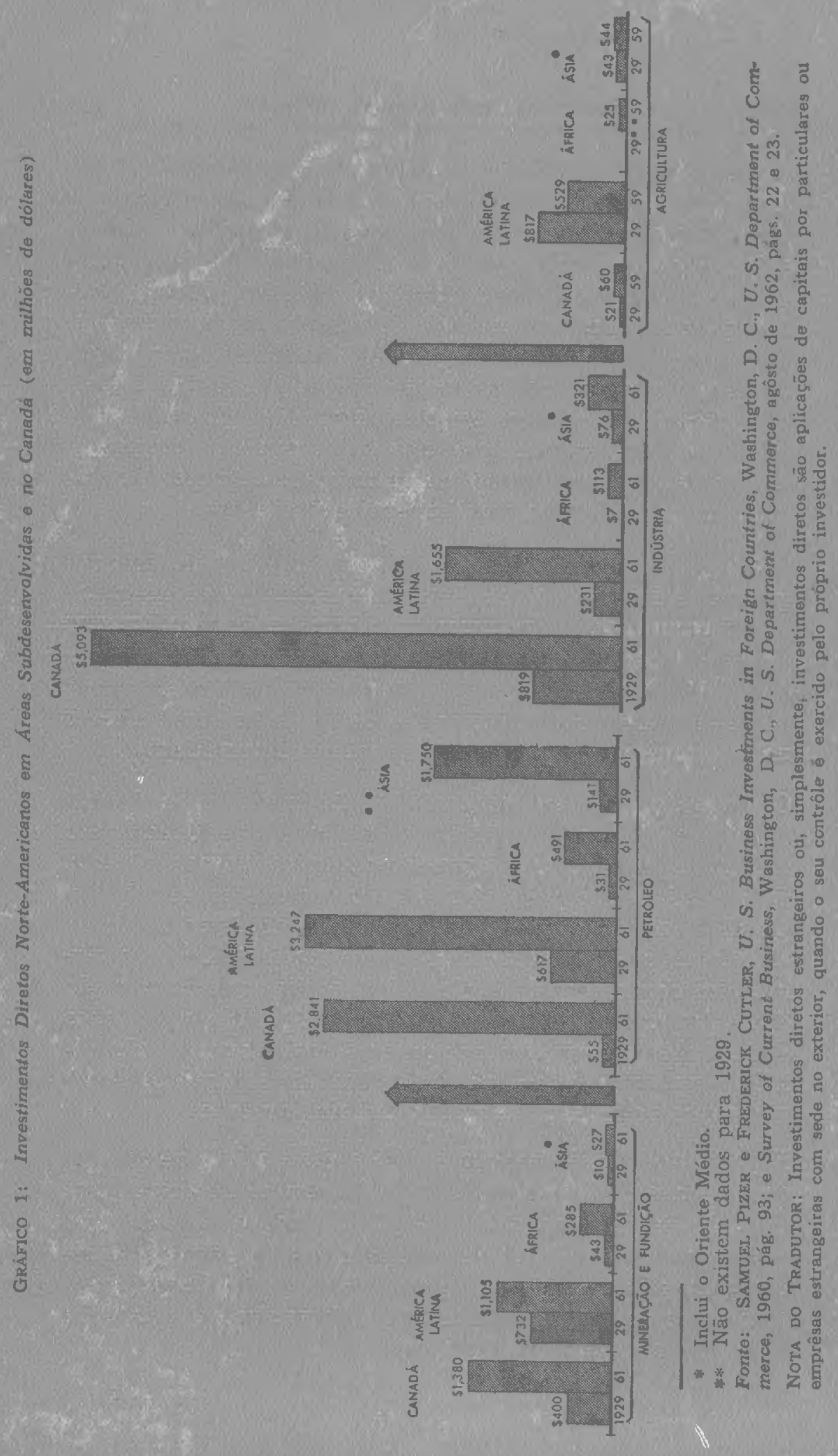


ANATOMIA DA HOSTILIDADE

A primeira vista o investimento estrangeiro em instalações fabris deveria parecer ir ao encontro de tôdas as aspirações dos latino-americanos ou de outros povos de áreas menos desenvolvidas. Êsse investimento traz capital exterior e tecnologia para o setor da economia que se julga ser o de maior necessidade de desenvolvimento - o setor industrial. Sua identificação com a nação hospedeira parece integral; seu crescimento depende do crescimento dos mercados internos do país. Ainda assim, a hostilidade em relação ao investimento norte-americano em áreas como a América Latina não parece estar diminuindo, mas sim crescendo atravês dos anos; na verdade, ela existe atualmente não só entre os intelectuais, mas também em grande parte dos economistas do Govêrno e de outros técnicos. Assim sendo, é bem provável que a reação reflita algo mais do que recordações da história dos primitivos investimentos. Que será?

\section{O Caso das Matérias-Primas}

Alguns dos fundamentos da hostilidade seriam provàvelmente melhor analisados e compreendidos por um psicólogo social do que por um economista. O melhor que podemos fazer neste momento é avaliar as reações que se apresentam sob a forma de argumentos econômicos.

A despeito das recentes mudanças na natureza do investimento estrangeiro, os investimentos diretos norte-americanos na agricultura e na mineração em áreas subdesenvolvidas ainda se aproximam dos que se fazem na indústria manufatureira. (Esta comparação não inclui a categoria muito especial dos investimentos petrolíferos, que por sua própria natureza é suficientemente grande para desfazer o equilíbrio.) Enquanto existirem essas proporções, os técnicos dos países em desenvolvimento continuarão relacionando o seu desagrado pelo investimento direto estrangeiro com o seu desaprêço mais geral pela especialização na exportação de matérias-primas. 
As razões para êsse desaprêço enchem muitas estantes das bibliotecas que tratam do desenvolvimento econômico. Evidencia-se, por exemplo, que os técnicos supõem:

- que os preços das matérias-primas, a longo prazo, tendem a diminuir em relação aos preços dos produtos manufaturados, penalizando, destarte, qualquer país que viva da exportação de matérias-primas e importe produtos manufaturados;

- que as indústrias extrativas de matérias-primas tendem a distribuir escassamente quaisquer dos benefícios do desenvolvimento para fora das áreas dos enclaves nos quais operam;

- ainda pior que os enclaves tendem a atrair e reter aquelas poucas pessoas de iniciativa e educação que existem nos primitivos estágios do desenvolvimento de uma sociedade, privando de seus escassos serviços disponíveis o resto do país.

A evidência de tôdas essas afirmações, como de costume, é ambígua. Por alguns períodos, para alguns produtos e em alguns países o argumento dos técnicos parece razoàvelmente coreto. Para qualquer leitura atenta dos fatos parece, por exemplo, que - surpreendentemente pouco se beneficiou o México, no período de 1910 a 1938, com as operações das companhias petrolíferas estrangeiras; mas, dificilmente seria possível chegar à mesma conclusão quanto às atuais operações das companhias petrolíferas da Líbia, na Argentina, na Venezuela ou no Kuwait. Podese duvidar sôbre qual o benefício para o Congo (ex-)Belga com as seis ou sete décadas de mineração estrangeira de diamantes; mas seria difícil denegrir os investimentos dos plantadores estrangeiros de borracha na Malásia ou a mineração estrangeira de bauxita na Guiana Holandesa. Seja o que fôr que técnicos das áreas subdesenvolvidas possam pensar do investimento estrangeiro nas indústrias extrativas de matérias-primas, os empresários norte-americanos, desconhecedores dessa disputa em particular, po- 
deriam pensar que serão benvindos - ou que deveriam ser benvindos - os investimentos estrangeiros nos empreendimentos industriais. E mais uma vez sua maneira de pensar estaria em desacôrdo com a realidade das áreas subdesenvolvidas. Vamos tratar de alguns aspectos nos quais o pensamento dos empresários norte-americanos muito provàvelmente parecerá ingênuo.

\section{Balanço de Pagamentos}

A primeira e mais importante das divergências é a respeito dos efeitos sôbre o balanço de pagamentos, provocados pelo capital direto estrangeiro. Constitui grande surprêsa para muitos empresários norte-americanos descobrir que muitos dos economistas das nações subdesenvolvidas consideram êsse tipo de investimento estrangeiro como sucção - não como refôrço - para a posição do balanço de pagamentos do país. Assinalam os técnicos (corretamente, como se pode verificar pelo Gráfico 2) que para grande parte das áreas e para a maioria dos tipos de investimento direto o capital adicional enviado pelos investidores estrangeiros é, a cada ano, menor que a sucção provocada pelos dividendos e royalties remetidos no mesmo ano, relacionados com os investimentos já existentes no país. Os economistas latino-americanos referem-se ao investimento estrangeiro, portanto, como "descapitalizador" de suas economias; e muitos insistem que êsse investimento é prejudicial sob o aspecto do balanço de pagamentos.

$O$ argumento pode ser considerado boa propaganda, mas não é boa ciência econômica. Os efeitos sôbre o balanço de pagamentos, mesmo das mais simples formas de investimento, são extremamente complexos. Compreendem não só o influxo original de capital e a posterior saída de dividendos, mas igualmente o impacto direto e indireto do investimento sôbre as importações e exportações do país. Por exemplo:

\footnotetext{
- Presume-se que as indústrias de substituição às impcrtações poupem divisas (embora, é claro, o montante de divisas poupadas se reduza à medida que os materiais importados sejam utilizados).
} 
Também é provável que as indústrias de produção para exportação aumentem o ganho da nação em divisas (embora, mais uma vez, o efeito possa ser contrabalançado por maiores importações).

Tôdas essas $€$ aquelas indústrias prcduzem efeitos adicionais sôbre a curva de importação e exportação através de seu impacto sôbre a renda e os preços.

\section{GrÁftco 2: Movimentos de Capitais de Emprêsas Notte-Americanos nas Nações Subdesenvolvidas}

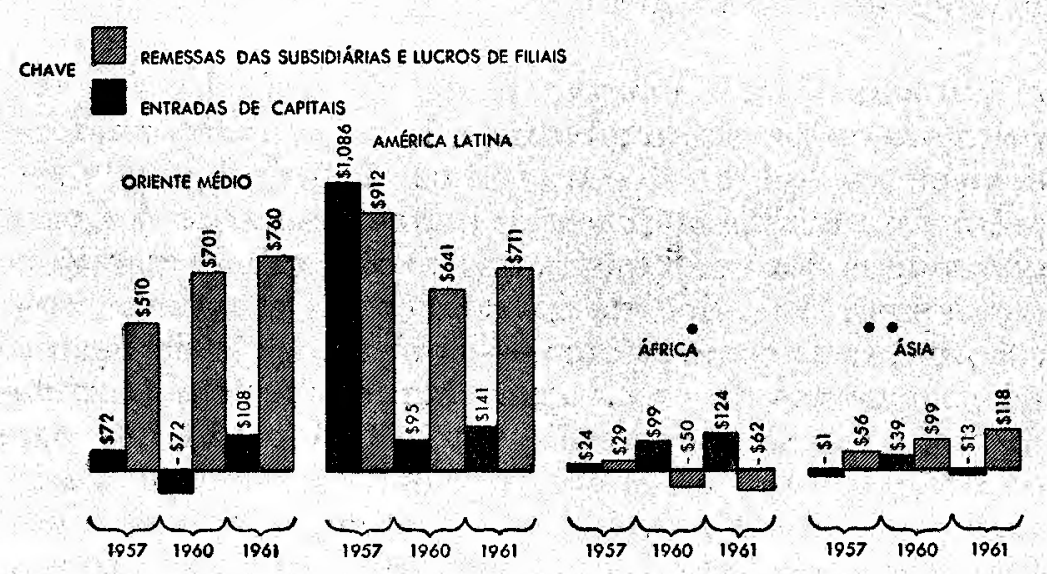

* Não inclui a União Sul-Africana.

* Não inchui a Austrália, o Japão e a Nova Zelândia.

Fonte: Survey of Current Business, Washingun, D. C., U. S. Departmen. of Commerce, agôsto de 1959, págs. 30 e 31; agôsto de 1961 , págs. 22 \& 23 , e agôsto de 1962, págs. 22 e 23.

Levando-se na devida conta todos êsses efeitos, o impacto líquido sôbre o balanço de pagamentos poderá ser tanto favorável como desfavorável. No caso do México, por exemplo, estou convencido de que o investimento direto estrangeiro traz importante contribuição à posição do balanço de pagamentos do país. Mas não existe nenhuma razão a priori para que assim deva ser em todos os países; em outras economias e em outros períodos pode ser que ocorra o contrário. 
Não obstante, a resposta dos empresários norte-americanos ao ataque de seus críticos é, por vêzes, tão incompleta e insustentável quanto o próprio ataque. A chapa padronizada de resposta é que a "verdadeira" contriburção dos investimentos estrangeiros consiste em muito mais do que o capital injetado na economia do país onde é aplicado. Há, também, substancial reinvestimento dos lucros auferidos no país, bem como boa-vontade em levantar empréstimos locais para aumentar o investimento industrial.

Quem argumenta dessa maneira está imaginando, por certo, que o crédito e os bens locais de capital, que a emprêsa estrangeira passou a mobilizar, não teriam tido emprêgo ou seriam ineficientemente utilizados. Imagina essas companhias como agentes capitalizadores que reúnem os recursos improdutivos de uma nação subdesenvolvida num todo em funcionamento e produtor; e não se contesta que algumas vêzes se justifique essa maneira de pensar. Sucede que em países onde são escassas as fontes locais de crédito industrial, onde existem poucos bens de capital, a resposta costuma surtir o mesmo efeito que a agitação de uma bandeira vermelha, em praça de touros, numa tarde de domingo. Porque em tais nações essa resposta significa que os escassos recursos locais - que doutra forma poderiam ser produtivamente utilizados pelos naturais do país, desejosos e capazes de empregá-los - são arrematados pelos estrangeiros através de seu maior poder de compra.

\section{Anseios de Exportação}

Os técnicos das áreas subdesenvolvidas professam também suas preocupações a respeito da política de exportação das indústrias estrangeiras. Atualmente é alto o custo de produção da maioria dos produtos industrializados dos países subdesenvolvidos. Mas essa situação não deverá subsis- 
tir para sempre; na verdade, já se está modificando para vários produtos, com o aumento da escala de operações em algumas áreas subdesenvolvidas. A questão significativa, entretanto, é se as subsidiárias de emprêsas estrangeiras no mercado local - fábricas de rádios, geladeiras, produtos alimentícios e outros - estão ou não dispostas a exportar quaisquer dêsses produtos para os grandes mercados dos países industrializados.

Com efeito, a exportação não tem representado muito até agora. Embora não se tenham dados exatos, as exportações das subsidiárias de emprêsas norte-americanas localizadas nos países subdesenvolvidos parece terem representado menos que 250 milhões de dólares em 1957. Ao observar o reduzido índice de exportação, os técnicos aludem tristemente aos acôrdos para utilização de marcas e patentes, à política dos distribuidores e a outros fatôres que podem tornar embaraçosas essas exportações, ou mesmo completamente impossíveis, ao modo de ver da matriz. E é bem de ver que os técnicos podem estar certos. Assim, existem verdadeiros problemas relacionados com os investimentos estrangeiros, que justificam preocupações tanto por parte do país investidor, como do país onde os fundos são investidos. Não obstante, os economistas dos países subdesenvolvidos levam, algumas vêzes, muito longe suas alegações quanto ao comportamento da subsidiária estrangeira, especialmente quando caraterizam as atividades dessas subsidiárias no campo da produção de artigos anteriormente importados.

E perfeitamente claro que muitas emprêsas estrangeiras, localizadas em áreas menos desenvolvidas, foram inicia!mente organizadas para prestar a menor contribuição possível à produção destinada à redução das importações do país onde se instalaram. Muitos dêsses investimentos foram feitos, inicialmente, por fôrça de contingências. Senão, vejamos: 
Havendo estabelecido rendoso mercado de exportação em certa área subdesenvolvida, emprêsas norte-americanas perceberam que seu mercado se tornava ameaçado por restrições à importação. Em resposta, algumas dessas companhias relutantemente montaram instalações no país, as mais limitadas possíveis, apenas para assegurar-se do mercado local. Os fabricantes de automóveis instalaram fábricas ùnicamente para montagem de automóveis. As indústrias farmacêuticas estabeleceram pequenos estabelecimentos locais para mistura e embalagem dos ingredientes importados a granel. Nesses casos as fábricas locais nada mais eram do que departamentos da matriz norte-americana ou européia, que davam os últimos retoques num produto já fabricado.

Nos últimos anos essa situação tem-se modificado ràpidamente, pelo menos na América Latina. Sob pressão do país, emprêsas estrangeiras foram forçadas a utilizar, em crescente proporção, as fontes locais para suprimento dos materiais necessários. Têm-se verificado problemas de qualidade e prazo de entrega, inevitáveis quando se negocia com fornecedores inexperientes; mas êsse problema não tem sido insuperável. A despeito dessas mudanças, muitos economistas das áreas subdesenvolvidas continuam aludindo às indústrias estrangeiras como indústrias de montagem ou fábricas para simples empacotamento. A ilusão persiste, embora os dados sugiram, de maneira bastante clara, a conclusão contrária.

Na América Latina, por exemplo, as fábricas locais das emprêsas norte-americanas compram agora no mercado local a maioria dos seus materiais, e pouco importam diretamente de sua matriz nos Estados Unidos ou de qualquer outra fonte estrangeira. A rapidez com que se está verificando a integração pode ser demonstrada pelo fato de que em 1955 um aamostra bem grande de companhias norte-americanas da América Latina relatou haver comprado sòmente cêrca de $56 \%$ de materiais, suprimentos $\mathrm{e}$ equipamentos nos mercados locais. Mas em 1957 as compras locais de materiais e serviços, de acôrdo ainda com relatórios de emprêsas norte-americanas que operam nessas áreas, aumentaram para $82 \%$.

\section{Monopólio Ianque versus Monopólio Doméstico}

Pode ser que no devido tempo a confiança dos técnicos, economistas e intelectuais das nações menos desenvolvidas 
seja restaurada em relação a muitos dêsses pontos. Mas, outro tipo de preocupação irá provàvelmente persistir: a preocupação baseada no problema dos monopólios internos. Os mercados internos da maioria dos países subdesenvolvidos, de maneira geral, são pequenos e limitados. A.política de restrição à importação geralmente os isola da concorrência estrangeira. Dessa maneira, são grandes as possibilidades de que sòmente pequeno número de emprêsas produtoras venha a dominar o mercado local.

Os intelectuais latino-aməricanos não se abatem fàcilmente com a existência de monopólios industriais. Embora a Constituição Mexicana proíba frontalmente o monopólio, tendo outras cartas constitucionais restrições similares, a realidade dos negócios latino-americanos é tal que constitui razidade a verdadeira concorrência de preços no mercado interno de produtos manufaturados. O problema na mente da maioria dos intelectuais latino-americanos, portanto, não está em tolerar o monopólio. Ao contrário, o problema é o seguinte: quem deverá controlar os monopólios que irão existir inevitàvelmente? É melhor que seja um natural do país, de acôrdo com a suposição quase universal, do que um estrangeiro. E é melhor por diversas razões: primeiro, porque os lucros monopolistas ficarão de posse da família nacional; segundo, porque a aplicação dos contrôles oficiais de preços, se necessários, irá provocar um problema puramente domést: :o, e não uma disputa internacicnal.

Como a maioria da longa lista de queixas com as quais se defronta o investidor estrangeiro, esta também, em parte, tem sólido fundamento; em parte, não procede. A observação tem indicado que, de um industrial norte-americano que desfrute de posição monopolística num pequeno mercado protegido, pode-se geralmente esperar que venha a estabelecer seu preço um tanto abaixo do negociante local, igualmente localizado. Talvez essa diferença ocorra porque a margem usual do produtor norte-americano é influenciada por normas estabelecidas em mercados mais competitivos, com os quais está acostumado; ou, talvez, 
por sua suposição, não muito bem conhecida pelos empresários locais, de que a procura agregada é realmente muito sensível às diferenças de preços, e será tanto inaior quanto menores forem os preços. Ainda assim, pode-se compreender e mesmo apreciar a relutância dos intelectuais latino-americanos em permitir que monopólios locais venham a cair em mãos estrangeiras.

\section{Quão "feio" é o norte-americano?}

Pode haver mais uma última razão para a mal disfarçada hostilidade de muitos líderes das nações menos desenvolvidas para com o investimento estrangeiro; e talvez seja a mais importante de tôdas. É a situação criada pelas relações entre os representantes das companhias estrangeiras e os representantes do país hospedeiro.

Os funcionários principais e os líderes intelectuais de muitas das grandes nações subdesenvolvidas constituem um escol que, por um ou outro meio imperfeito, se salienta entre dezenas de milhões de pessoas. E, de maneira crescente, constituem unna "elite" sofisticada, educada nas melhores escolas estrangeiras ou guindadas ao tôpo por pura habilidade natural.

Os principais representantes das emprêsas estrangeiras com os quais êsses líderes entram em contato diário são, quase todos, estrangeiros; e a prática de colocar estrangeiros na administração de cúpula é ainda, segundo várias pesquisas sôbre o assunto, a política dominante. Êsses administradores estrangeiros - se minha observação sôbre companhias norte-americanas que operam no exterior pode ser considerada representativa - são geralmente bem treinados e competentes, o que é típico dos escalóes médios que constituem a administração das grandes emprêsas. Entretanto, exceção feita a alguns casos raros e impressivos, êles não são - e nem seria de esperar que fôssem - equiparáveis, cultural, intelectual e socialmente, à elite nacional com a qual contatam. Mesmo assim, 
em qualquer encontro com os líderes locais, o gerente estrangeiro, sob certo aspecto, apresenta-se como representante de uma cultura mais poderosa e avançada, indispensável ao bem-estar do hospedeiro. A fraqueza humana sendo o que é, e o amor próprio sendo o mais precioso tesouro do homem, pode-se fàcilmente imaginar o impacto cumulativo dêsses encontros sôbre a elite local. Talvez seja êsse o busílis, no final das contas, que representa o papel mais importante nas reações adversas dos líderes das nações subdesenvolvidas.

E VOCE, EMPRESARIO? .

Não é novidade para os empresários norte-americanos que na maioria das nações subdesenvolvidas êle deverá viver hostilizado, ativa ou latentemente, pelos publicitários, professôres e funcionários governamentais. $\mathrm{O}$ para que pode não estar preparado é que seria melhor não contar muito, também, com as simpatias dos empresários de Bombaim, Medelim, São Paulo ou Manila. Na verdade, seria bom que estivesse preparado contra certa reesrva oculta, talvez mesmo hostilidade, por parte dos empresários locais .

Essa hostilidade não acontece sempre. Enquanto um país ainda não está fortemente empenhado no processo de industrialização os mais importantes comerciantes locais estão usualmente em campos de atividade que se completam - em vez de concorrer - com o investidor estrangeiro. Prestam serviços às minas estrangeiras, aos campos de petróleo e às plantações, com materiais e transporte locais, facilidades bancárias, serviços de utilidade, e assim por diante. Nessas atividades podem surgir, de vez em quando, problemas com as emprêsas estrangeiras; mas êsses problemas não alteram o fato de que nesse ambiente não estão em conflito básico os interêsses a longo prazo das emprêsas estrangeiras com os interêsses dos negociantes locais.

Todavia, uma política deliberada de industrialização tende a mudar tudo isso. Restrições na importação são aplica- 
das a fim de preservar o mercado local aos que têm fábricas localizadas no país. Isenções fiscais, créditos industriais especiais e vários outros atrativos são oferecidos. Uma vez aplicadas essas restrições e atrativos, geralmente novos empresários entram em cena. Alguns, como foi observado, são estrangeiros; entretanto, muitos são locais e financiados internamente.

Quase tôdas as grandes nações subdesenvolvidas que seguiram a política de restrição à importação lograram estimular o crescimento de uma classe média empresarial nacional, fortemente vinculada ao crescente setor industrial do nôvo país. Deve-se ter em mente as circunstâncias nas quais êsses grupos floresceram. Como alguns dos primitivos industriais norte-americanos, êles devem, em parte, seu primeiro impulso de crescimento à nova política de proteção nacional; seu caminho foi facilitado por favores fiscais; e tiveram seus mercados ampliados por compras do govêrno. Em muitos casos foram alimentados por culturas que pouco ou nada hauriram das filosofias de Adam Smith ou Thomas Jefferson. Não se pode imaginar êsse terreno como adequado a empresários norte-americanos interessados em promover princípios que impliquem na completa liberdade de concorrência ou na mínima interferência governamental.

\section{Concorrência Desleal}

A falta de identificação entre muitos empresários das nações menos desenvolvidas e seus colegas estrangeiros é aumentada por vários fatôres. Um dêles é o sentimento dos empresários locais de que as emprêsas estrangeiras constituem concorrência desleal. Existem muitas razões para êsse sentimento:

- Em primeiro lugar, os produtores estrangeiros se estabelecem no mercado local apoiados por conhecido nome comercial ou marca de fábrica firmados em base das importações anteriores. 
Acima disso, geralmente o produtor estrangeiro tem muito mais fácil acesso ao crédito internacional (ou assim parece aos produtores locais em maiores dificuldades). Ao passo que o produtor local paga de 12 a $20 \%$ de juros, fato caraterístico da falta de capitais na maior parte da América Latina e na Ásia, a matriz da emprêsa estrangeira local pode usualmente conceder crédito a sua subsidiária a taxas de juros muito menores.

Ao insulto se junta o prejuízo quando o crédito é restringido nos mercados locais; e o prejuízo se multiplica por muitas vêzes, aos othos dos competidores locais, quando a restrição de crédito é feita como medida antiinflacionária, sob pressão de ricas nações credoras ou do Fundo Monetário Internacional. Porque então, quando para a companhia local são cortadas as fontes de crédito por pressões externas, a subsidiária estrangeira ainda pode utilizar as fontes internacionais para quaisquer créditos adicionais. No fim a subsidiária estrangeira é vista como um dragão que esmaga deslealmente, em seu caminho, a fraca oposição local.

Evidentemente, os produtores locais não estão em desesperada desvantagem quando enfrentam essas dificulidades; dificilmente teriam sobrevivido se as dificuldades fôssem insuperáveis. De várias maneiras conseguiram vencer algumas de suas desvantagens competitivas: gerando, através dos lucros, ampla fonte interna de recursos; entrando em contrato de licenciamento com emprêsas estrangeiras; contratando técnicos estrangeiros e, depois, treinando téenicos locais; criando, através da propaganda, suas próprias marcas locais; e finalmente, em alguns casos, trazendo 0 auxílio governamental a fim de cercear a subsidiária estrangeira.

O México, em especial, elevou a novas alturas o processo sutil e difuso da intervenção do govêrno em favor das emprêsas nacionais. Não seria inteligente supor que outros paises não venham também a levar a coisa a tão longe quanto o México, desde que se sintam capazes. E tão 
cedo isso venha a ocorrer, o empresário norte-americano que investiu nesses países achará ainda mais difícil entrar em acôrdo ideológico com o seu competidor local.

A despeito de tôdas essas dificuldades, existe base para movimento mùtuamente vantajoso de investimento direto estrangeiro da nação avançada para outra menos desenvolvida. Não é base fundamentada na idealogia comum, mas que se origina de interêsses compatíveis. Para o investidor estrangeiro tal interêsse deveria ser o fito de lucro.

Em alguns ramos industriais das nações subdesenvolvidas as oportunidades de lucro excedem, consideràvelmente, as existentes nos Estados Unidos. Os dados oficiais a respeito, é verdade, não são muito encorajadores. Os investimentos diretos norte-americanos nas indústrias da América Latina, por exemplo, geralmente mostram um lucro líquido anual de sòmente 12 a $13 \%$ sôbre o patrimônio liquido contábil, conforme relatório do Departamento de Comércio dos Estados Unidos. Minha impressão, porém, é que o retôrno real é provàvelmente bem maior quando se incluem todos os efeitos dos preços de transferências entre firmas, pagamentos de royalties, despesas administrativas e outras. De qualquer forma, as oportunidades individuais de investimento podem ser muito mais lucrativas do que-a média global.

Quanto aos interêsses da nação onde o investimento é feito, a motivação para o convite ao investimento direto estrangeiro é tão óbvia quanto a precedente. Em muitos ramos da atividade econômica, nos vários estágios de desenvolvimento, a desejabilidade da admissão de investidores diretos estrangeiros se evidencia em razão da tecnologia, da habilidade e do capital que êstes têm para oferecer.

O de que o investidor estrangeiro necessita em tais casos é continuidade de segurança (entendida no mais alto sen- 
tido, isto é, incluindo-se garantia não sòmente contra a nacionalização, mas também contra a discriminação e a perseguição). Por outro lado, o de que os govêrnos de muitos países subdesenvolvidos necessitam é alguma indicação de que um dia, se o desejarem, poderão ser capazes de trazer a emprêsa para o âmbito da propriedade nacional.

Muito se tem pensado sôbre o sistema do empreendimento conjunto como resposta parcial a problemas como êsse. Tal sistema, entretanto, apresenta seus decisivos limites. Algumas pesquisas indicam que a maioria dos investidores norte-americanos ainda preferem subsidiárias estrangeiras nas quais exerçam total contrôle e ainda operam geralmente nessa base. Ao mesmo tempo, os negociantes locais preferem dirigir seu próprio negócio, sem interferência de estrangeiros . Quando alianças se realizam, entretanto, são da espécie explosiva; verificam-se freqüentemente desespêro e constrangimento de uma espécie ou de outra.

Não obstante, quando possivel a organização de um empreendimento conjunto, essa poderá ser a melhor solução possível. Mas, quando impossível, ainda deverá haver alguma base para investimento de empresários estrangeiros nas áreas subdesenvolvidas, mùtuamente vantajoso tanto para o investidor como para o país.

\section{Garantias Reciprocas}

Talvez pudesse ser elaborada uma linha de solução se os investidores estrangeiros estivessem preparados, desde 0 início, a aceitar sua permanência como de duração limitada, e nessa base elaborassem seus cálculos. Essa aceitação poderia ser feita na forma de oferta para, em data prefixada, ser vendida parte do capital da emprêsa aos nacionais do país, de acôrdo com programação acertada prèviamente e a preços a serem estabelecidos por fórmula e procedimento satisfatórios. Existem muitas dificuldades para qualquer solução dêsse tipo, delas não sendo certamente a menor a de se acharem compradores particulares, bem como a de estabelecer o preço para a venda das 
ações. Em alguns países menos desenvolvidos o início de um mercado de ações sugere a possibilidade de eventual solução para ambos problemas.

Uma cláusula dessa espécie pode satisfazer algumas das necessidades psicológicas e políticas das nações subdesenvolvidas. Isso poderia ser assim, mesmo que as vendas de ações nunca fôssem efetuadas em quantidades significativas. Mas difícilmente se podesia esperar que o acôrdo viesse a encorajar o investimento direto estrangeiro, a menos que fôsse associado a alguns direitos e garantias para o investidor. A garantia mais lógica seria a do "tratamento nacional", isto é, garantia contra perseguição e contra discriminação, baseada na propriedade estrangeira da emprêsa.

Êsse tratamento é agora garantido aos investidores norteamericanos em muitas nações por vários acordos bilaterais, como o Acôrdo de Amizade e Administrativo. Na verdade, contudo, êsse tratamento ainda constitui ideal remoto. $O$ ideal e a realidade talvez pudessem ser aproximados se a garantia de tratamento nacional fôsse apoiada por um fundo de indenização e por uma côrte internacional, para os quais os investidores tivessem acesso direto. É uma solução que pode justificar perfeitamente o patrocínio da Aliança para o Progresso como medida tangível em favor da futura posição dos investidores particulares no $\mathrm{He}$ misfério Ocidental. 